\title{
Reorganizing the Ummah: COVID-19 and social transformation in plural society
}

\author{
A.A. Widianto*, L.A. Perguna, T. Thoriquttyas \& F. Hasanah \\ Universitas Negeri Malang, Malang, Indonesia
}

\begin{abstract}
COVID-19, which has hit various countries in the world, has brought significant changes to social life. In this context, the pandemic has also contributed to social transformation in the plural society in Sukoreno. Sukoreno village is known as the village of Pancasila because of its religious pluralism. This study aims to describe the impacts of a pandemic on a plural society and ways to respond to it. This research uses qualitative methods with data collection through interviews and observations. Interviews were conducted with village officials and religious leaders. The data analysis technique used was an interactive model. The results of this study indicate that the COVID-19 pandemic has led to socio-religious transformation. Various policies, regulations and agreements related to handling COVID-19 changed socio-religious routines and interfaith social relations. Routines and annual religious activities should be modified according to health policies and protocols. On the other hand, there has been a strengthening of interfaith relations in dealing with the pandemic's impact. Interfaith collaboration or community gathering forums (SILAMAS) are formed by optimizing their respective resources to help people who need assistance. This social reality further emphasizes that the pandemic, on the one hand, results in social transformation and affects social relationships between elements of society.
\end{abstract}

Keywords: Ummah, plural society, Desa Pancasila

\section{INTRODUCTION}

The world is facing a COVID-19 catastrophic outbreak, which until now its spread is increasing in several countries, including Indonesia. In Indonesia, there has been a rapid increase of people infected with COVID-19. From only 2 positive cases announced on March 2, 2020, on May 20, it has reached 18,496 positives, 4,467 recovered, and 1,221 deaths (World Health Organization 2020). In practice, various legal products and policies for handling COVID-19 are not effective in suppressing the escalation of the number of cases in Indonesia (Djalante et al. 2020). One of the causes is the policy crisis in handling COVID-19 (Widianingrum \& Mas'udi 2020; Hidayat 2020). In addition, the policy approach tends to be top-down and without optimizing the potential of local culture and institutions. In fact, various levels and community institutions are very prospective in helping to handle COVID-19 (Djalante et al. 2020).

The increasing spread of COVID-19 in Indonesia is a serious problem in the medical field and in other strategic fields at various levels. In the socio-religious aspect of society, COVID-19 has had an impact on changing patterns of worship due to restrictions on mass worship activities (Post 2020). Even though the restrictions were applied, some communities violated them, creating new distribution clusters (Quadri 2020). On the other hand, religion can play a productive role as well.

The impact of COVID-19 also targets the people of Jember as a melting pot area where various ethnic groups mingle and coalesce, especially in the Sukoreno village Jember, which is as popular as

*Corresponding author: ahmad.arif.fis@um.ac.id 
Pancasila Village because it can build religious harmony. Religious adherents in Sukoreno consist of 7152 Muslims, 35 Protestants, 110 Catholics, 124 Hindus and 15 Buddhists (BPS 2018) as well as followers of the Sapta Darma and Ilmu Sejati beliefs. Apart from its plurality, Sukoreno Village was chosen because its people can maintain social cohesion and harmony amidst diversity. The tolerance of the Christian-Muslim community in Jember is also driven by ethnic and cultural similarities and the equality of socio-economic classes (Mamuaya \& Sair 2017). Post-religious conflict resolution is also built on local wisdom and obedience to religious leaders (Putra 2013).

Several studies show that many interfaith institutions have not been optimized even though they have contributed to the handling of COVID-19, such as the Indonesian Ulema Council (MUI), the Indonesian Church Association (PGI), the Indonesian Buddhist Council, and so forth (Djalante et al. 2020). In the context of a plural society, religious diversity can be a potential resource in dealing with COVID-19. However, most of them present a limited contribution. In fact, these resources will certainly be more productive if they are engaged in interfaith cooperation relations. Therefore, it is crucial to see the impact of the pandemic on socio-religious life and the response of the interfaith community in handling COVID-19 in plural societies. This study aims to describe the local community's response across religions against the pandemic and map the social-religious changes.

\section{METHODS}

This research was conducted in Sukoreno Village, Umbulsari District, Jember Regency. The focus of this research was geographic and sociological, which described the complexity of community relations in the social spaces within it. The subject of this research was the Sukoreno community, which consisted of plural social elements, especially multi-religions and religious sects. This research used qualitative methods to explore data and an in-depth understanding of social phenomena (Silverman 2005)

Data collection was carried out through observation with the aim of (1) understanding social settings naturally, (2) capturing events that affected social processes and the focus of research, (3) identifying the regularity or repetition of social realities in society, and (4) understanding social reality from a research subjects' perspective (Black \& Champion 2009). Observations were carried out in a participatory manner in the Sukoreno community, focusing on observing social processes, social institutions and structures, patterns of interaction and relationships between religious groups, ongoing traditions, symbols and social realities that influence the focus of this research. To enrich the data, interviews were conducted with informants to obtain a comprehensive picture of the required data. Informants were selected based on the purposive informant selection technique, based on the ability and accuracy of the informant regarding the required data.

\section{RESULTS AND DISCUSSION}

\subsection{Socio-historical context of plural society in Sukoreno, Jember}

Jember, which is the focus of this research, is prone to religious conflict, but also has positive potential in building social harmony and cohesion as in the Sukoreno village. Quoting Casanova (in Sumrahadi 2018), in religion, two identities are attached at once. One side of religion is exclusive, particular and primordial. On the other hand, religion displays inclusiveness and transcendentalism as well. Religion can act as social glue or break the existing harmonies between religious communities (Nottingham 1993, Thomas O‘dea 1987).

In the context of Jember, several studies discuss religious pluralism and religious-based conflicts. These studies discuss: (1) the ethics of the Pandalungan community in creating diversity (religion) (Sair 2019); (2) tolerance of the Madura Muslim-Christian community in the Sumberpakem Village (Mamuaya \& Abdus Sair 2017); (3) harmonization of diversity and interfaith dialogue in Sukoreno 
Jember (Rosadi 2018); (4) the "Sunni-Shia" religious conflict in the Puger District (Izzati 2018); (5) the role of local wisdom in the resolution of religious belief conflicts in East Java (Putra 2013); and (6) communal consolidation as mitigation of religious conflict in East Java (Fattah 2018).

Jember is an area that has cultural and religious diversity. This can be oriented towards the extent of existing social and religious conflicts of Shia and Sunni conflict in the Puger District, Jember (Ghufron 2015). In addition, there are also counter-arguments that occur in the Puger community regarding the assumption of taking lsut in Islamic law (Qomariyah \& Sholihin 2019). Various roots of conflict in the Jember area can be attributed to the existing culture in the region. Pendhalungan is a cultural aspect is an effort to assimilate tribes and their differences (Sasmita \& Endang Widuatie 2016). Besides various conflicts that exist in the Jember region, strengthening the aspect of tolerance in Sukoreno Village plays a role in modeling for other areas experiencing religious and cultural disintegration.

According to data on religious diversity in Jember BPS Provinsi Jawa Timur (2016), it is recorded that Jember contained 2.294.519 Muslims, 28.926 Protestants, 19.288 Catholics, 1.609 Hindus, 3.401 Buddhists and 343 other believers. Multiculturalism is an ideology that can achieve a prosperous community life (Suparlan 2014). Sukoreno Village, which has been lined up to become the Pancasila village in the Jember Regency, demonstrates religious harmony by the residents harmonizing with each other and holding religious ceremonies or celebration of the holidays of each of the existing religions.

Discussions about religion have never been questioned by residents. This is due to the high tolerance and understanding of individuals and religious groups to respect each other religions. The main aspect that encourages social cohesion among them is the difference in religious differences that already existed and were brought by ancestors so that the issue of identity never seems to gain traction. However, that does not mean that there have never been conflicts between religions.

\subsection{Pandemic and social transformation in Sukoreno}

In following up on local government appeals and regulations in implementing policies to anticipate and prevent the spread of the Coronavirus, on March 26, 2020, body temperature checks were held when Hindus were about to perform worship at the temple in the Ngembak Geni ceremony at Swasty Dharma Temple in Sukoreno Village, Umbulsari, Jember. There are also rules for washing hands and using hand sanitizers provided by local health center officers who joined as a health unit in this Hindu event. Hindus who entered the temple were told they must also go through a disinfectant spray.

The formulation of policies in Sukoreno village certainly comes from above, where the district government stipulates that each village must meet health protocols in carrying out all existing activities. In addition, the village of Sukoreno itself has its health protocol at each place of worship. The COVID policy's termination in Sukoreno village was approved by the local village head and decided as an index of health protocols in the Suskoreno area.

In handling COVID-19 in Sukoreno, the interfaith community also played an active role in handling the COVID task force, COVID volunteers and youth organizations. The involvement of interfaith community leaders is based on the principle of cooperation and harmony among fellow citizens. The local people never question each other's religion in this matter. The enthusiasm of the interfaith community was manifested when carrying out tightening health protocols at guard posts between regions, as well as during religious activities, wherein this case it was found that when carrying out Eid prayers in 2020, which was in the midst of the pandemic the previous day, parking guards and health workers maintained order within the interfaith community. This was intended to ensure conducive conditions in the mosque, and vice versa. As for the COVID formation mechanism, it was initiated by the local village government and youth organizations by conducting deliberations with religious leaders and then religious leaders channeling it to congregations, so that the formation of an interfaith COVID volunteer team was formed to secure the Sukoreno village. 


\subsection{The power of cross-religion solidarity in managing the pandemic}

As explained above, in preventing the spread of COVID, all Sukoreno residents joined in handling COVID through the village COVID task force team, COVID volunteers, and youth organizations. Each of these communities cooperates with each other in Sukoreno village. Each community function is divided based on its work assignments. The assignments consist of spraying regularly at every resident's house, maintaining monitoring posts, collecting data on vulnerable people based on age and immune systems due to illness, providing social assistance to poor people, especially widows and maintaining order when carrying out religious activities. In their respective duties, the community can contribute to each other to maintain the village's security and its people, so that the problem of practicing religion is sidelined to realize the social activities that are being carried out.

All this COVID collaboration has also led to deeper intimacy between communities. The community does not depend on the COVID handling community alone, but all local people are harmonious to maintain and obey the existing health protocols in Sukoreno village. The collaboration results in no people identified as being infected by the Coronavirus, so the village or area is categorized in the yellow zone.

In anticipating COVID-19 in Sukoreno, there are many rituals and religious ceremonies that are independent of the existing village government policies. Rituals and religious ceremonies are carried out by each religion with the religious leaders who guide the running of these rituals. This form of ritual is allowed by the village government to follow up on the prevention of COVID-19, which can disturb the local community. The people of Sukoreno also still believe that COVID-19 is a "pagebluk" which is a deadly disease without illness, so anticipation also comes from the local community by performing rituals in their respective religions. Of course, this ritual has received permission from the local village.

\section{CONCLUSION}

The COVID-19 pandemic has resulted in social changes in the people of Sukoreno Jember. The socio-religious life was reorganized in accordance with national policies and community consensus. Annual activities involving many parties must be modified to prevent the spread of the virus. One of the most affected aspects is the existence of restrictions on religious activities that cause crowds. Local-scale social restrictions reduce religious activity. However, few people still continue to carrying out congregational worship activities while still implementing health protocols. The social restriction policy during COVID-19 indirectly helped strengthen interfaith social relations in dealing with the impact of the pandemic. The leaders organize the resources they have in each congregation to work together to help restore the social conditions of the people affected by the pandemic. Through this collaboration, social relations become stronger and more productive for the community. This shows that in addition to changing socio-religious life, the pandemic has also affected inter-religious social ties based on local wisdom.

\section{REFERENCES}

Alfandi, M. 2013. Prasangka: Potensi Pemicu Konflik Internal Umat Islam. Jurnal Walisongo, Volume 21, No. 1. 23-41.

Berman, Yitzhak.2003. Indikators For Social Cohesion. Austria:The European Centre For Social Welfare Policy and Research.

BPS Kabupaten Jember. 2018. Kecamatan Umbulsari Dalam Angka 2018. Jember: BPS Jember.

Djalante, R., Lassa, J., Setiamarga, D., Sudjatma, A., Indrawan, M., Haryanto, B., Mahfud, C., Sinapoy, M. S., Djalante, S., Rafliana, I., Gunawan, L. A., Surtiari, G. A. K., \& Warsilah, H. 2020. Review and analysis of current responses to COVID-19 in Indonesia: Period of January to March 2020.

Faisal, Sanapiah. 2015. Pengumpulan Dan Analisis Data Dalam Penelitian Kualitatif. Dalam Burhan Bungin. Analisis Data Kualitatif. Jakarta: Grafindo Persada. 
Hamdi, Ahmad Zainul. 2013. Radicalizing Indonesian Moderate Islam From Within the NU-FPI Relationship in Bangkalan, Madura Journal of Indonesian Islam. Volume 07, No 01. 46-61.

Hidayat, R. 2020. Teledor Penanganan Wabah COVID-19 di Indonesia. tirto.id. Retrieved May 20, 2020, from https://tirto.id/teledor-penanganan-wabah-COVID-19-di-indonesia-eDPG

Ihsan Ali-Fauzi Rudy Harisyah Alam Samsu Rizal Panggabean. 2009. Pola-Pola Konflik Keagamaan Di Indonesia (1990-2008). Jakarta Kerjasama Yayasan Wakaf Paramadina (YWP) Magister Perdamaian Dan Resolusi Konflik, Universitas Gadjah Mada (MPRK-UGM), the Asia Foundation (TAF).

Izzati, Arini Robbi. 2018. Konflik Agama Antara "Sunni-Syiah" Di Kecamatan Puger, Kabupaten Jember. Dalam Optimalisasi Peran FKUB Mewujudkan Indonesia Damai. Penyunting Eko Riyadi \& Despan Heryansyah. Kalam: Jurnal Studi Agama Dan Pemikiran Islam, Vol. 7, No. 1. 67-82.

Luthfi Assyaukanie 2018. Akar-Akar Legal Intoleransi Dan Diskriminasi di Indonesia.

Maarif, Ahmad Syafii 2012. Politik Identitas Dan Masa Depan Pluralisme Indonesia Dalam Ihsan Ali-Fauzi Dan Samsu Rizal Panggabean. Politik Identitas Dan Masa Depan Pluralisme Kita. Jakarta: Democracy Project Yayasan Abad Demokrasi.

Mahli Zainudin Tago. 2013. Agama Dan Integrasi Sosial Dalam Pemikiran Clifford Geertz.

Mamuaya, Chriestine Lucia \& Abdus Sair. 2017. Toleransi Masyarakat Islam-Kristen Madura Di Desa Sumberpakem, Kecamatan Sumberjambe, Kabupaten Jember. Dimensi. Vol. 10. No.2, 76-86.

Mappiase, Sulaiman \& Muliadi Nur. 2007. Investigasi Konsep Pluralisme Keagamaan dan Loyalitas Masyarakat kepada Tokoh Agama di Sulawesi Utara. Laporan Hasil Penelitian Kompetitif Kolektif Terpadu 2007.

Mohammad Takdir 2017. Identifikasi Pola-Pola Konflik Agama Dan Sosial (Studi Kasus Kekerasan Berbasis Sektarian Dan Komunal di Indonesia). Jurnal RI'AYAH, Vol. 02, No. 01. 15-32.

Muqoyyidin, Andik Wahyudin 2012. Potret Konflik Bernuansa Agama di Indonesia (Signifikansi Model Resolusi Berbasis Teologi Transformatif). Analisis, Volume XII, Nomor 2. 60-74.

Nottingham, Elizabet K. 1993. Agama Dan Masyarakat: Suatu Pengantar Sosiologi. Jakarta: Rajawali Press

Post, T. J. 2020. Religion and COVID-19 mitigation. The Jakarta Post. Retrieved May 20, 2020, from https://www.thejakartapost.com/academia/2020/03/26/religion-and-COVID-19-mitigation.html

Progress in Disaster Science, 6, 100091. https://doi.org/10.1016/j.pdisas.2020.100091

Quadri, S. A. 2020. COVID-19 and religious congregations: Implications for spread of novel pathogens. International Journal of Infectious Diseases, 96, 219-221. https://doi.org/10.1016/j.ijid.2020.05.007

Reychler, Luc. 2006. Challenges of Peace Research. International Journal of Peace Studies, Volume 11, Number 1, Spring/Sumer, 2006.

Ridwan, MK. Adang Kuswaya, Muhammad Misbah. 2016. Agama; Antara Cita Dan Kritik.

Rosadi Br. 2018. The Harmonization of Diversity and Interreligious Dialogue in Sukoreno Village Jember. International Journal of Management and Administrative Sciences (IJMAS), Vol. 6, No. 2, (11-19).

Sair, Abdus 2019. Etika Masyarakat Pandalungan Dalam Merajut Kebhinekaan (Agama). Jurnal Sosiologi Pendidikan Humanis JSPH Vol. 4. No 1. 12-32. 